Recibido: 12 febrero 2019 | Aceptado: 4 octubre 2019 | Publicado: 1 diciembre 2019

Cita: Narbona, A. (2019). El estudio de la sintaxis del español coloquial (balance provisional). Normas, 9, 138-159. doi: https://doi.org/10.7203/Normas.v9i1.16167

\title{
EL ESTUDIO DE LA SINTAXIS DEL ESPAÑOL COLOQUIAL (BALANCE PROVISIONAL)
}

THE STUDY OF COLLOQUIAL SPANISH SYNTAX (CURRENT STATE)

\section{Antonio Narbona}

Universidad de Sevilla

Resumen

La celebración del II Congreso Internacional del español hablado, al cumplirse los 25 años del Grupo Val.Es.Co., es una excelente ocasión para realizar un balance de lo que se ha hecho y de lo que aún falta por hacer. Pero el creciente interés de los lingüistas por el análisis de la oralidad lo convierte inmediatamente en provisional y limitado. Estas reflexiones se centran sólo en los estudios que tratan de sintaxis, y la atención se fija en los problemas (teóricos, metodológicos, prácticos) con los que ha habido que enfrentarse, bastantes de los cuales aún no están resueltos. El futuro y la proyección social de la investigación se abordan brevemente en la parte final.

PALABRAS CLAVE: oralidad, español coloquial, sintaxis, pragmática.
Abstract

The "Il Congreso Internacional del español hablado", ( $2^{\text {nd }}$ International Conference of Spoken Spanish), to be held on the 25th anniversary of the Group Val.Es.Co., makes it necessary to assess what has been done or what there is still to be done. The current status can only be provisional, due to the increase of interest among linguists in the analysis of oral language. Similarly, it is limited due to the fact that these studies focus on colloquial Spanish syntax and attention is drawn to the problems (theoretical, methodological, practical) that arise and the need to find solutions. The future and the social scope of this field of investigation are briefly discussed in the final part.

KEY WORDS: Oral language, colloquial Spanish, syntax, pragmatics 


\section{INTRODUCCIÓN}

0. En una disciplina como la lingüística, cuyos avances suelen producirse como una lenta espiral en la que cada vuelta apenas se aparta de la anterior, resulta inusual el interés creciente por el español coloquial en los últimos decenios. Tras algunas contribuciones anteriores (Narbona 1988, 1990, 1991, 1992, 1993a, 1994, 1995; Cortés Rodríguez 1992, 1994; Vigara 1992; etc.), puede decirse que el impulso decisivo se produce tras la reunión sobre El español coloquial. Análisis del discurso oral que, coordinada por Luis Cortés, se celebró en la Universidad de Almería a finales de noviembre de 1994 -hace 25 años- y la que doce meses después tuvo lugar en la de Valencia (Pragmática y gramática del español hablado). En un cuarto de siglo se ha ido asentando como materia de enseñanza en la mayoría de nuestras Facultades de Filología, y el número de publicaciones específicas ha sido y sigue siendo tal, que varias veces ha habido que realizar el "estado de la cuestión", como los de Luis Cortés (1996, 2002a, 2002c), que, además, lleva mucho tiempo cumpliendo una encomiable labor compilatoria en la Revista Oralia.

El balance que sigue, además de provisional (las propias intervenciones en este II Congreso Internacional del español hablado obligarían a modificarlo), por fuerza ha de ser limitado. Únicamente voy a referirme a algo de lo ya logrado y de lo mucho que falta por hacer en el ámbito de la sintaxis.

1. Pese a que cada vez somos más los que pensamos que la investigación del español coloquial debe comenzar por y centrarse en su peculiar técnica de construir y organizar los enunciados (oracionales o no), no todos parecen convencidos de que no se trata de dar con otra sintaxis, sino de contribuir a conocer mejor la del español, sin adjetivos. No hay que empeñarse en descubrir a cada paso singularidades, rarezas o "perlas preciosas" precisamente en la(s) variedad(es) de que nos servimos todos -no por igualcotidianamente.

No defiendo, entiéndase bien, que la sintaxis deba situarse por encima del léxico. Pero de las expresiones con que obviamente se logra el sentido de los moldes constructivos ¿cómo reconocer las coloquiales? ${ }^{1}$ ¿no son de uso general desde luego, en tal caso, al azar, en principio, por último, sin duda, estar a régimen, estar de enhorabuena, echar de menos, ir de compras, merece (o vale) la pena, pagar al contado (o en metálico), poner en claro, caer en la tentación y muchas más de las que figuran en el Diccionario del español coloquial, de A. Ramos y A. Serradilla (2000), destinado a la enseñanza del español para extranjeros? $Y$ es fácil de entender por qué algunas no se emplean más que en situaciones de confianza y proximidad: echar un polvo, estar de puta madre -o

${ }^{1}$ Es engañosa la percepción intuitiva de que un discurso queda marcado por unas pocas que parecen serlo. Si, por ejemplo, de "Me jode ir al Kronen los sábados por la tarde porque está siempre hasta el culo de gente. No hay ni una puta mesa libre y hace un calor insoportable. Manolo, que está currando en la barra, suda como un cerdo", arranque de Historias del Kronen (llevada al cine posteriormente con notable éxito), de José Ángel Mañas, finalista en un prestigioso premio literario por -a juicio del jurado- su "fidelidad al lenguaje popular", eliminamos el término puta y sustituimos jode por molesta, hasta el culo por lleno y currando por trabajando, nada queda de tal estilo en la sintaxis, que no puede ser más "canónica" y estándar. 
jodido-, mandar a la mierda -o al carajo, a tomar por saco, etc.-, ir de culo, poner a parir, bajarse los pantalones, dar un braguetazo, ser la hostia -o un coñazo-, etc. ${ }^{2}$

Es en el complejo proceso de enunciación que conduce a los enunciados donde hay que buscar inicialmente las claves para entender cómo los hablantes, además de información, transmitimos ideas, sentimientos, intenciones..., y, sobre todo, para averiguar si conseguimos o no los efectos buscados, es decir, si hacemos con las palabras todo lo que nos proponemos (López Serena 2017).

2. Que, pese a reconocerse su decisivo papel, la sintaxis -casi ausente en la dialectología y en la sociolingüística- siga siendo un hueco o asunto pendiente, nada tiene de extraño. Pero no porque la creencia de que "a hablar se aprende hablando" (frente a "la letra con sangre entra") haga pensar que no cabe esperar que en el lenguaje hablado familiar vaya a descubrirse mucho que merezca la pena, sino sencillamente porque no acabamos de hacernos con los principios explicativos e instrumentos analíticos adecuados para alcanzar una descripción satisfactoria, que únicamente se conseguirá cuando se aclare -si ello es posible- la cuestión de la relación entre teorías y datos (Narbona 2003a). El día en que se haga la historia -"tumultueuse et changeante"de los segundos (la de las teorías ha sido trazada reiteradamente), se pondrá de manifiesto que ha sido "particulièrement intèressante et révélatrice" la etapa abierta por la incorporación "des données orales", desatendidos a causa de la "réaction de rejet et de méfiance qu'elles ont longtemps suscitée" (Willems 1998: 80). En realidad, más que resistencia a acogerlos ${ }^{3}$, lo que ha habido es confusión acerca de lo que ha de entenderse por datos orales y a la hora de distinguirlos de los que no lo son, o, mejor, lo son menos, pues estamos ante un continuum. Una construcción como el gato, que ha tirado un vaso (en tanto que respuesta a ¿qué ha sido eso?) quizás sea "exclusiva de la oralidad", pero no por el hecho de "no corresponderse con ninguna de las descritas por la sintaxis del español", sobre todo, si se reconoce seguidamente, con razón, que no puede explicarse en términos sintácticos, sino que debe "interpretarse en un marco pragmático y discursivo" (Borreguero 2015: 119).

Es lógico que apenas haya observaciones sintácticas en el pionero El español coloquial, de W. Beinhauer, cuya primera edición alemana es de 1929, pero que se tradujo -de la segunda- varias décadas después. No se entiende, en cambio, que más de sesenta años después A. M ${ }^{a}$ Vigara (1992) organizara su Morfosintaxis del español coloquial (en realidad, la obra responde más bien a su subtítulo: Esbozo estilístico) con idénticos ejes vertebradores ${ }^{4}$. Observaciones sistemáticas propiamente sintácticas -sumadas a otras morfológicas, léxicas y prosódicas- se encuentran en El español conversacional en el coloquio, de A. Briz (1998), articuladas en torno a presuntas categorías pragmáticas (de

\footnotetext{
${ }^{2}$ No se recogen mala leche, mala uva o malafollá, ni ninguna expresión con huevo(s).

${ }^{3}$ Pese a que la NGRAE se propone prestar atención a todas las variedades -entre ellas, tanto "a las que se asocian con los discursos formales como con el habla coloquial"-, reconoce que "a los REGISTROS o ESTILOS, es decir, a las variedades coloquial, espontánea u otras" se atiende "de manera más limitada", y que los datos "de procedencia oral" aparecen "en proporción menor" que los extraídos de textos "literarios, ensayísticos, científicos y periodísticos" (Cfr. Narbona 2013a, 2016a)

"Los "principios de organización discursiva" que "rigen el uso coloquial”, son, para Vigara, la expresividad, "reflejo espontáneo de la afectividad del hablante" (casi la mitad del libro de Beinhauer se dedica a "La expresión afectiva"), la comodidad (Beinhauer habla de economía), y la adecuación.
} 
ahí quw el autor la haya subtítulado Esbozo de pragmagramática) sobre las que habré de volver.

Entre los factores que han contribuido a la marginación del análisis de la técnica libre del discurso, se encuentra el sesgo escriptista (o escriturista) que ha presidido la elaboración del saber gramatical, que ha llevado a considerar inferiores y deficitarias las actuaciones coloquiales y a tildar a no pocos de sus enunciados de incompletos o inacabados ${ }^{5}$, cuando no de erróneos o incorrectos. Creo que la definición de gramática como el "arte de hablar y escribir correctamente" (papel que no puede ni le corresponde cumplir) no se hubiera mantenido durante siglos de no ser por la implícita aceptación de que el hablar se supedita al escribir, cuando en realidad, desde todos los puntos de vista lo primero es anterior a lo segundo (Narbona 2016b) ${ }^{6}$.

Ha pesado también, quizás más, el hecho de que tanto en la denominada gramática tradicional, como en los modernos modelos estructurales funcionales (centrados en el sistema o código) y, sobre todo, formales (que se ocupan de la competencia de un hablante-oyente ideal), las secuencias (muchas de ellas acuñadas ad hoc) se hayan observado como productos monologados, sin contarse con interlocutor alguno. Á. López García, que en el inicio del primer volumen de su Gramática del español (1994) ya arremetía contra los que se valen de ejemplos del tipo el niño come manzanas o Alfredo da un libro a Juan ("¿ha dicho alguien alguna vez estas frases en su vida?", se preguntaba), ha llegado a afirmar posteriormente que "en realidad, cuando Chomsky habla de 'hablante nativo ideal', se está refiriendo claramente a un 'oyente nativo ideal' que suministra al lingüista juicios de aceptabilidad. $Y$ añade que "si hubiera partido de los datos del hablante, nunca habría basado sus argumentos en frases extravagantes de su propia invención y que jamás han dicho los anglohablantes, pasando por alto, sorprendentemente, las que sí emiten" (López García 2018: 43). Está claro que lo que se reclama, y con urgencia, es el retorno a interlocutores reales. Y digo retorno, porque, por ejemplo, hace casi un siglo escribió Amado Alonso (1935) que "en el lenguaje realmente coloquial (o en escritos que lo representan) con grandísima frecuencia el diminutivo supone una corriente activa o emotiva (o combinada)" con que el hablante "presiona al oyente", esto es, que "frente a la poesía o la prosa, en que servirá para la efusión y la representación, en el coloquio tiene un valor activo"7.

3. Quizás no sobre recordar que la preterición de la sintaxis coloquial es también una consecuencia más de la deformación jerárquica del lingüista, quien, por un lado, no duda

\footnotetext{
${ }^{5}$ No podía sospechar que cuando en 1989 escribí que ciertas construcciones "han de contemplarse como acabadas y completas, no truncadas ni elididas, precisamente en cuanto suspendidas", iban a ser objeto de tanta atención, hasta el punto de convertirse recientemente en el objeto de la Tesis Doctoral de V. Pérez Béjar, Pragmática de las estructuras suspendidas, defendida en la Universidad de Sevilla (2018a). Cfr. Pérez Béjar 2018b.

${ }^{6}$ Se advierte en el título de no pocas obras, como la de Juan de Robles, impresa (probablemente en Alcalá de Henares) en 1565: Arte para enseñar muy breve y perfectamente a leer y escrevir assí en castellano como en latín, según la propiedad de cada una destas lenguas, muy provechosa para los que comiencan [sic] las letras, y aun para los que están principiados en grammática.

${ }^{7}$ He tenido ocasión de comprobar más de una vez que se olvidan (o desconocen ) ideas muy atinadas . En una Comunicación "Sobre las propiedades anafóricas y catafóricas de los sintagmas nominales escuetos en español", presentada en el XXIX Simposio de la SEL (Cáceres 1999), Isabel Pérez Jiménez y Norberto Moreno Quibén no mencionaron ni uno solo de los clarificadores trabajos de R. Lapesa sobre el sustantivo sin actualizador (dame pan, compra melocotones, frente a *dame

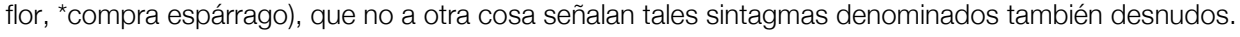


en asignar el status de invariante a una forma en particular y carácter marcado a las demás ("sus" variantes), pero, por otro, se erige en representante de (todos) los "hablantes", incluidos los muchos (la mayoría) que no tienen -ni pueden tenerconciencia de estar sirviéndose de una de esas presuntas "variantes" (Simone 1997). Para que la gramática pueda salir del callejón en que parece estar quedando bloqueada (Kerbrat-Orecchioni 1986) sería preciso: a) elaborar una atinada descripción de las variedades en -no con- que realmente viven las lenguas, y b) proyectar con acierto -en la medida de lo posible- el principio de la relatividad de la variación, es decir, dejar de observar la lengua como un objeto homogéneo de referencia lógicamente precedente. Lo segundo es muy difícil de llevar a la práctica en sintaxis, por resultar "fortemente antieconómico e in alcuni casi irrealizabile" (Sornicola 2002). Y en cuanto a lo primero, si bien contamos con intentos loables para abordar global y adecuadamente las modalidades de uso -como el de P. Koch y W. Oesterreicher $(1990,2000)$, para los que todas, orales y escritas, han de contemplarse como pertenecientes a una escala única, no jerárquica, gradual y pluriparamétrica, que iría desde el polo de la inmediatez al de la máxima distancia-, es mucho lo que falta por hacer. En la práctica, no resulta sencillo determinar en qué zona de la serie escalar se ubica cada una de ellas, aunque, en el fondo, todo tiene que ver con el grado de complicidad y connivencia entre los que intervienen en el acto comunicativo ${ }^{8}$.

4. Los asuntos que requieren solución son tantos, que no es fácil decidir por dónde comenzar ${ }^{9}$. Parecería obligado por las unidades operativas, pero no lo haré, pues únicamente tengo claras dos cosas, y en ninguna soy muy "original".

En primer lugar, que no hablamos con o por oraciones. De hecho, el propio término oración se está viendo desplazado por nociones menos comprometedoras, como estructura o construcción, aunque en la Nueva Gramática de la lengua española (RAE/ASALE 2009) reiteradamente se califique la segunda de "vaga"10.

En una conferencia subtitulada "Una respuesta a una pregunta de Antonio Narbona", impartida en mi Facultad de la Universidad Hispalense el 9 de marzo de 2004, Salvador Pons trató de contestar a la que yo me había hecho a mí mismo casi quince años antes, en el Congreso que la Sociedad Española de Lingüística celebró en Tenerife con motivo de su vigésimo aniversario, “¿Es sistematizable la sintaxis coloquial?”, que reformulé, nada más empezar, así: "¿se descubre en la modalidad coloquial un conjunto estructurado de esquemas de organización sintáctica más o menos regulares y constantes?" Aunque no era, ni mucho menos, la primera vez que en el Grupo Val.Es.Co. se planteaba la necesidad de contar con un sistema de unidades (Briz I

\footnotetext{
${ }^{8}$ La propuesta de los dos lingüistas alemanes no se concibió, ni mucho menos, como cerrada, Cfr. Rey Quesada 2018.

${ }^{9} \mathrm{Sin}$ olvidar el obstáculo que supone el que, a juzgar por la frecuencia con que se oyen -y se leen- expresiones como "dicho coloquialmente", "para decirlo en términos coloquiales" y otras similares, cualquiera, menos el lingüista, cree saber lo que es o no es coloquial.

${ }^{10} \mathrm{Con}$ todo, la sombra de la oración sigue siendo "alargada", como lo refleja el nutrido número de apellidos que se le aplican. Se habla de oraciones simples, suspendidas, escindidas, dislocadas... Para junio de 2019 está prevista la celebración en Helsinki de un Simposio sobre "Desviación lingüística: funciones de las construcciones sintácticas marcadas en las lenguas románicas y en finés", en el que, como estructuras "marcadas", esto es, "que divergen de la frase canónica", se citan, entre otras, las dislocadas (a la izquierda y a la derecha) y las "oraciones hendidas y pseudohendidas". Y, además de las tradicionales coordinadas y subordinadas, se han ido poniendo en circulación, con mayor o menor éxito, denominaciones como inordinadas, interordinadas, cosubordinadas, insubordinadas. Y a cuanto no encaja en el núcleo de la unidad oracional se califica de periferia oracional (o de elemento extraproposicional).
} 
Grupo Val.Es.Co. 2003a, 2003b), y de otros (Padilla 2002), en Oralia (2003) apareció, firmada por todos sus miembros, la que calificaron de "primera presentación de conjunto provisionalmente definitiva". No lo fue (definitiva, quiero decir), ni parece que lo haya sido tampoco el "examen crítico" con criterios "esencialmente pragmáticos" publicado en el núm. 35 de Estudios de Lingüística del Español (2014,13-73), dedicado monográficamente a la cuestión ${ }^{11}$, pues -reconocen- "sus resultados tendrán que implementarse mediante aplicaciones" con el fin de "mejorar los postulados mediante reformulaciones parciales sucesivas" (p. 15) ${ }^{12}$. Y, a juzgar por lo oído en la mesa redonda que en este mismo // Congreso se dedicó a "Unidades del discurso y lengua hablada", las dudas no van a quedar despejadas en un corto plazo. Según A. Hidalgo, el "carácter provisional" de la propuesta y las continuas discusiones dentro del equipo reflejan los innumerables problemas con que "nos estamos encontrando". En esto último insistió S. Pons, que llegó a hablar de "peleas" internas en el seno del grupo por tal asunto. Por su parte, X. Padilla (que también se había ocupado de la cuestión con anterioridad, 2006) cerró su intervención haciéndose preguntas (sin respuesta), y aludiendo a la falta de desarrollo de alguna de las unidades y a las flaquezas de la definición de todas.

Quizás el reflejo más claro de la voluntad de desanclarse del esquema oracional sea la inabarcable y exponencialmente creciente bibliografía generada en torno a los denominados marcadores (u ordenadores) del discurso ${ }^{13}$, un conjunto abierto de expresiones heterogéneas y polifuncionales ${ }^{14}$ que algunos prefieren calificar de partículas discursivas y otros simplemente de partículas.

Mi segunda observación, tan poco novedosa como la anterior, tiene que ver con el decisivo papel de los mecanismos prosódicos. Se solía prestar atención a aquellas secuencias a las que se atribuye entonación "neutra" o "no marcada". Pero ¿cabe hablar de neutralidad entonativa?

\footnotetext{
${ }^{11}$ Coordinado por Luis Cortés, que también se ha ocupado del asunto, en solitario (2002b) o en colaboración (Cortés / Camacho 2005).

${ }^{12}$ En un trabajo de 2011 sobre las causales denominadas de la enunciación (para mí de una significación especial, y no sólo por su indudable calidad científica), A. Briz insiste en que, mientras la oración se sitúa en la dimensión gramatical, el acto se encuadra en la del discurso, que requiere un enfoque pragmático

${ }^{13}$ En este mismo II Congreso, inaugurado con una Ponencia en la que E. Ridruejo no eludió "sumergirse en este océano". se les ha dedicado una sección especial, y mientras se desarrollaban sus trabajos supe de la publicación de Beyond Grammaticalization and Discourse Markers, editada por S. Pons y Ó. Loureda (2018). A la avalancha de trabajos he aludido recientemente (Narbona en prensa). Aparte de los intentos de establecer un inventario descriptivo (SANTOS RíO 2003; BRIZ / PONS / PORTOLÉS 2008; Fuentes 2009; etc.) y de las innumerables monografías (es seguro que el número de referencias de CORTÉS 1996 se ha más que duplicado en los últimos veinte años), no cesan de aparecer volúmenes colectivos específicamente dedicados a tales expresiones (MARTíN ZORRAQUINO / MONTOLÍO 1998; LOUREDA / ACÍN 2010; BORREGUERO / GÓMEZ-JORDANA 2015; etc.) y otros en los que de ellas se ocupan bastantes o algunas de las colaboraciones. Así, el número de RILCE correspondiente a 2014, coordinado por A. López Serena, monográficamente dedicado a Historia de la lengua e intuición, dos de las ocho colaboraciones tratan, respectivamente, de no obstante (Garachana) y de o sea (Pons Bordería); un tercio de las páginas de Oralia (2016) se dedican a ¡Ni hablar! (Anais Holgado), ya te digo (Salvador López Quero) y algunos reformuladores explicativos (o sea, igual, digamos, en todo caso, de todas maneras, bueno) en el español oral de Santiago de Chile (Abelardo San Martín); etc.

${ }^{14}$ En su estudio de vamos, C. Fuentes (1998) habla de su "compleja polifuncionalidad" desde el título mismo, una complejidad que, es de suponer, se vería acentuada en pero vaya y pero vamos, consideradas por Polanco (2013, 2014a, 2014b) unidades diferenciadas. Para Pons Bordería (2014, 2016), o sea es "el más polifuncional de los marcadores de reformulación", de ahí que pueda sustituir al resto (es decir, esto es, a saber, en otras palabras).
} 
Como también de la prosodia se ha ocupado el grupo Val.Es.Co., en particular algunos de sus miembros (véanse al final algunas referencias bibiográficas de A. Hidalgo -quien en un trabajo aún sin publicar, que aprecio no sólo por lo que tiene de rigor científico, ha realizado un resumen de los avances, y algún que otro retroceso, en los últimos veinte años-, X. Padilla o A. Cabedo (2006, 2007a, 2007b), que trata aquí mismo de la "configuración prosódica de algunos géneros discursivos"), me limitaré a recordar que casi cuarenta años antes de que en el G(roupe) A(ixois de) R(echerches en) S(yntaxe) se propusiera el concepto noyau para designar "la partie de l'énoncé offrant une autonomie intonative et syntaxique" (Blanche Benveniste 1997), S. Gili Gaya -con un criterio que calificó de psicológico- había definido las oraciones como "unidades de atención y de sentido reveladas por la curva melódica". Y antes aún (en ¡1925!), A. Alonso, al percatarse de que "la carencia de sentimiento de nuestro idioma impidió a insignes filólogos alemanes [Meyer-Lübke, Gessner, Weigert, Spitzer, entre otros] llegar a una solución aceptable" de los problemas que plantean el origen y la significación de como que y cómo que (-¿Cómo que no vienes? -Como que no voy), presentes ya en textos medievales, escribió unas páginas admirables para poner de manifiesto que la clave está en el contorno melódico (Narbona 1996b).

No es necesario insistir en el poder de la prosodia (Narbona 2009). De la conformación entonativa depende, por ejemplo, que, en la réplica, una secuencia encabezada por pero, lejos de contraponerse a la del interlocutor, refuerce su contenido (-Cuidado que es bestia tu hermano -iPero BÉSTIA!); que prescindir del término negativo no reoriente un juicio (i[No] vayamos a cometer otra vez la misma equivocación!); e incluso que se llegue a invertir su sentido, como en jno habla nada! 'no cesa de hablar, habla sin parar'; ¡tendrás quejas de mí! 'nada puedes reprocharme [hasta ahora]' (reacción a una previa advertencia conminatoria); janda que ha tardado bastante en dejarla! 'no ha tardado nada en dejarla'; janda que no se lo he dicho muchas veces! 'se lo he dicho muchísimas veces'; etc. (Narbona en prensa). No hace falta decir que los problemas se multiplican cuando se pretende hacer explícito cómo los rasgos prosódicos sirven para segmentar el fluir discursivo ${ }^{15}$.

5. Cabría plantear -es la pregunta que había anunciado- si, y hasta qué punto, es achacable el retraso de la investigación a los escollos, casi insalvables, a la hora de identificar y definir las unidades operativas. Pienso que la principal dificultad reside en la pretensión de lograr un sistema idóneo de unidades (ninguna de las cuales tiene por qué sustituir -mucho menos desbancar- a la oración) sin abandonar las secuencias acuñadas ad hoc. El coloquio no permite abordar más que actuaciones idiomáticas reales (no ideales) contextualizadas ${ }^{16}$, cuyo sentido intencional no se cierra al ser producidas por el emisor, sino con el descifrado inferido por el receptor. No se comprende que algunos prefieran continuar enrocados en esquemas formales fácilmemente manipulables. P. W. Culicover y L. Sainz-Maza, que dirigen un Proyecto de investigación de la Universidad Estatal de Ohio (USA), invitan a participar en una

\footnotetext{
${ }^{15}$ Todo un epígrafe (2.2.3.) dedica a la cuestión Pérez Béjar, que, tras comparar una decena de modelos, algunos "globales" (C. Fuentes; E. Roulet y Ginebra; S. Gutiérrez Ordóñez; Hengeveld / Mackenzie), y otros que adoptan la perspectiva de la Lingüística Textual (J. M. Adam), del Análisis de la Conversación (Val.Es.Co.; B. Gallardo Paúls) o simplemente la supraoracional (Cl. Blanche-Benveniste; A. Berrendonner), termina diciendo que cada uno "plantea criterios y enfoques distintos", por lo que únicamente cabe "reflejar que existe un ámbito más o menos común de estudio y que se dan en la actualidad multitud [sic] de propuestas que tratan de explicar fenómenos similares con sus propios criterios" (2018: 77).

${ }^{16} \mathrm{Si}$ se oye decir a menudo dice que una frase "se ha sacado de contexto", es porque nada hay "fuera de contexto".
} 
encuesta, en la que, una vez "ideada" la situación hipotética en que se formula cada pregunta, debe valorarse el grado de aceptabilidad (desde el 1 ["completamente inaceptable"] al 7 ["completamente aceptable"]), que no de corrección, de la contestación que se propone. Así, por ejemplo, en el marco ["María está hablando con su amiga Charo y le ha comentado que han salido unas ayudas económicas para la familia. Charo, muy interesada, le pregunta ¿Quiénes pueden solicitar esta ayuda económica?, a lo que María responde: Todo aquel que tenga dos hijos puede solicitarla"] se pregunta al encuestado si cree que puede pedirla alguien que tenga sólo un hijo, y se le sugiere que proponga alguna otra oración [sic] con el mismo [sic] significado. Es posible que bastantes de los que se hayan prestado a colaborar no hayan asignado la puntuación máxima a la contestación de María simplemente porque (aparte de considerar superfluo repetir puede solicitarla) estuvieran pensando en otras soluciones habituales: todos aquellos que, aquellos que, todos los que, los que, quienes, etc. ${ }^{17}$. El usuario tiende a resistirse a emitir juicio acerca de lo puesto en boca de interlocutores inventados por estudiosos que sólo buscan obtener una base de datos electrónica máximamente "objetiva" y "fiable", pretensión que no es de ahora. Hace más de cuarenta años, I. Bosque, para elaborar el corpus (aunque no lo considerara tal) que le iba a servir de punto de partida de su Tesis Doctoral Sobre la negación $(1980)^{18}$, nos pasó a algunos colegas un ejemplario de un par de centenares de frases (sin información contextual alguna) acuñadas por él y con una única instrucción: "Juzgar entre 4 y 0 la gramaticalidad [sic] de las siguientes oraciones [sic]". Recuerdo que no fueron pocas mis vacilaciones a la hora de asignar una de las cinco opciones en gran parte de los casos: Dudo que Manolo venga hasta las cuatro; En esa oficina sólo muy excepcionalmente se hace nada; Ernesto sólo trabaja más que cuando quiere; Antes de acabar todavía, hazme otra cosa; Sólo tres personas movieron un dedo por nadie; Es imposible que Antonio venga este fin de semana tampoco; Lo compró sin que valiera un pimiento; etc. No extraña que la introspección, que permite usar datos negativos, es decir, "secuencias agramaticales cuya inexistencia muestra alguna pauta consistente en el sistema gramatical", fuera la fuente de datos preferida en la Gramática descriptiva de la lengua española coordinada por este mismo autor y V. Demonte (1999: XXIX), pero sí que tal predilección llegue a ser compartida incluso por quienes se ocupan de fenómenos en que resulta improcedente, como María Luisa Zubizarreta, que en el capítulo 64 de esa obra se ocupa de las funciones informativas -o discursivas- tema y

\footnotetext{
${ }^{17}$ De modo parecido, en el contexto (imaginado) [“Vero se ha pasado una hora hablando por teléfono con Leyre. En cuanto ha colgado, el marido de Vero pregunta ¿Pero qué te ha contado Leyre?, y recibe esta contestación: Que Isabel ha dejado de fumar"], se solicita al encuestado que, además de valorar su aceptabilidad, responda, a su vez, a ¿Crees que Isabel era fumadora?, lo que resulta un tanto chocante, pues es indudable que, de no ser fumadora, la respuesta de Vero, si no es evasiva (trata de "echar balones fuera" para que el marido la deje en paz), resulta absurda. Igualmente sin sentido parece que, dentro del contexto ["Te has encontrado con Mario en el gimnasio. Has notado que estaba excesivamente contento, le preguntas ¿Por qué estás tan contento hoy?, y recibes esta respuesta: Porque Ana ha conseguido sacarse el carnet de moto"], se pregunte ¿Crees que Ana ha sacado el carnet de moto con dificultad? Claro que peor que inventar situaciones ficticias es enmendarle la plana a la realidad. Al reseñar (Boletín de Filología, XLII, 2007, 437-451) un trabajo mío (Narbona 2003b), dice J. J. Montes Giraldo a propósito de ¿¿Qué estabas / bebiendo otra vez agua del pozo?! (con que personalmente reconvine a mi padre, de sobra conocedor de que no era potable): “¿No habrá error en la segmentación, porque lo más natural en este contexto parece ¿Qué / estabas bebiendo agua del pozo?". Está claro que imaginó un "contexto" muy distinto, y si no pensó en otras posibilidades (hasta media docena improvisó Antonio Hidalgo cuando le hice la consulta: ¿que estabas bebiendo otra vez agua del pozo?, ¿qué estabas bebiendo / agua del pozo?, etc.) es sencillamente porque no se suele preguntar por lo evidente.

${ }^{18}$ Es mucho lo que después se ha publicado sobre un asunto tan problemático como la negación. Cfr. Touratier / Zaremba (2007).
} 
foco, y que, pese a considerar "particularmente relevantes" en la descripción el "orden de palabras" y "las propiedades entonativas", no utiliza más que ejemplos inventados ${ }^{19}$.

6. Integrar el contexto en la descripción implica situarse en el dominio de la pragmática, vía de aproximación a la comunicación que ha acabado "invadiendo" casi toda la investigación sobre el español coloquial ${ }^{20}$. En la Universidad de Valencia, donde en 1995 A. Briz y colaboradores organizaron la reunión sobre Pragmática y gramática del español hablado, a la que antes me he referido, tuvo lugar en noviembre de 2009 otra en que se prescindió del segundo término (Pragmática del español hablado), con el fin de debatir sobre las "nuevas perspectivas para el estudio del español coloquial". Un año antes, en 2008, había aparecido el libro Español coloquial, subtitulado por su autor, V. Gaviño, Pragmática de lo cotidiano ${ }^{21}$. Y algunas de las secciones del Congreso Internacional sobre "Enunciado y discurso: estructura y relaciones", celebrado a finales de 2016 en mi Universidad Hispalense se dedicaron a "Gramaticalización y pragmaticalización" y al "papel de la pragmática en la relación entre sintaxis, prosodia y semántica" 22 . Si no siempre hay que seguir un mismo orden, ni en igual proporción, al recurrir a las tres disciplinas, es porque las condiciones de cada acto comunicativo obligan a readaptar continuamente algunos de los principios pragmáticos. Lo que no procede es proyectarlos inadecuadamente de ellos, como hace Oaxana Danilova (2014) con las máximas conversacionales de Grice y el principio de relevancia de Sperber y Wilson, al no tener en cuenta la singularidad de unas actuaciones que, pese a su notable grado de coloquialidad, no pertenecen a la esfera de lo privado, pues el intercambio verbal se encuentra mediatizado por una presentadora-coordinadora que de antemano conoce las "contestaciones" de los participantes que más pueden "interesar" a la audiencia, cuyo aumento persigue a toda costa (Narbona 2015b) ${ }^{23}$.

\footnotetext{
${ }^{19}$ Lo que le obliga, claro es, a idear algún contexto para cada caso. Así, el ejemplo “...(En cuanto a) el hermano, parece que los padres hablan de él todo el tiempo" debe enmarcarse en el [Contexto: Discusión sobre la relación distante entre Juan y sus padres]. Y dentro de otra imaginada [Discusión sobre posibles candidatos para un cierto trabajo] ha de insertarse este otro: "Bernardo, sin embargo, estoy segura de que nadie confía en ese idiota", que califica de agramatical, al igual que cualquier posición del tema fuera de la periferia izquierda: "Estoy segura de que, Bernardo, nadie confía en ese idiota" (Vol. 3, p. 4221).

${ }^{20}$ Lluís Payrató, autor de Català col·loquial (Universitat de València, 1996), acaba de publicar un manual de pragmática (2018)

${ }^{21}$ En el que, por cierto, se afirma que el estudio del español coloquial "está viviendo su punto más álgido [sic]".

${ }^{22}$ En la Sección "Pragmática del español hablado" de este II Congreso se encuadraron trece Comunicaciones, a las que bien podrían sumarse las dieciocho de "Atenuación / Intensificación".

${ }^{23}$ He aquí, como muestra, lo que la autora considera un caso "claro" de transgresión de la máxima de cantidad. Patricia, la conductora del programa, va "acorralando" a la concursante (Juani) en una especie de interrogatorio calculado:

Patricia: estás aquí para hablar con un hombre...que te quiere. [LEE]: "no me rechaces, yo te quiero" ¿Quién es ese hombre? Juani: [Gestos, no responde]

$P$ : ¿no has rechazado a ningún hombre?

J: No

P: ¿no has rechazado...?

J: no

P: ¿algún hombre te quiere?

J: mi marío

P: tu marido

J: claro

P: normal, es tu marido

J: hmmm...

P: ¿has rechazado a tu marido?

J: no

P: pues entonces no será él.....
} 
7. Si tampoco me detengo en la "necesidad" de dar con amplias categorías pragmáticas que puedan servir de apoyo, es porque ello supone enfrentarse con más y nuevos problemas, para los que no tengo solución. Hasta las más asentadas, como la intensificación y la atenuación -no desligables de los mecanismos de [des]cortesía-, a las que tanta atención se ha prestado y sigue prestando ${ }^{24}$, suscitan dudas, sin que falte quien sostiene que ambas deben contemplarse como las dos caras de una misma moneda ${ }^{25}$. Desde luego, no parece que unas herramientas analíticas deban convertirse en objetivo único o principal de análisis, sobre todo si, como ocurre en Análisis del discurso de El arcano de la Quina de José Celestino Mutis, de J. M. Pedroviejo Esteruelas (2017), el texto que es objeto de análisis, de principios del siglo XIX, nada tiene de coloquial.

8. Cuanto más "coloquiales" (es decir, más alejados de la escrituralidad) sean los fenómenos, más y más difíciles de resolver serán los problemas sintácticos.

El escollo primero (no el más importante) al que hay que enfrentarse tiene que ver con la "necesidad" de poner por escrito (transcribir) lo oral, tarea especialmente complicada cuando se trata de conversaciones espontáneas. El sistema ideado por M. Criado de Val (1958), en el que, tras unas sucintas indicaciones acerca de las características de los participantes, de la situación de comunicación e incluso de los gestos que acompañan a lo verbalizado, figuran las transcripciones convencional y fonética de las intervenciones, así como del contorno melódico, es de muy difícil aplicación. Y aunque mucho se ha ido avanzando (Alvar / Villena 1994; Vila Pujol / Grupo GRIESBA 2001; Briz / Val.Es.Co 2002; Azorín 2002; Gómez Molina 2007; Moya 2008; Ávila / Lasarte / Villena 2008; Lasarte / Sánchez / Ávila / Villena 2009; etc.), el hecho de que algunos se decidan a ofrecer un abanico de propuestas (en el corpus coordinado por Moya [2008], la respuesta de una funcionaria con estudios medios a la pregunta ¿en qué consiste tu trabajo?, "transliterada" sin etiquetado soy lo que / aho- ahora nos han cambiado el nombre / antes éramos auxiliares de justicia, se etiqueta después -"para su mejor comprensión"- del siguiente modo: soy lo que / aho<palabra cortada / >ahora nos han cambia< $[d]>0$ el nombre / antes éramos <término>auxiliares de justicia <término>), revela que seguimos sin disponer de un sistema del todo convincente y satisfactorio.

\footnotetext{
Y así continúa el intercambio unos minutos más. Que las intervenciones de Juani, conocedora de que el receptor real de sus respuestas no es Patricia, sino millones de telespectadores, sean breves y en algún caso permanezca en silencio, poco tiene que ver con que se respete o no una máxima conversacional.

${ }^{24}$ Sin salir del círculo valenciano (también por la Universitat de València se publicó en1997 La atenuación en el castellano de Chile: un enfoque pragmalingüístico, de Juan Puga Larraín), de ellas se ha venido ocupando desde muy pronto A.Briz (1995), que prefiere hablar de estrategias intensificadoras (Briz en prensa), y bajo su dirección realizó Marta Albelda su Tesis Doctoral La intensificación como categoría pragmática: revisión y propuesta (2007), quien -con la colaboración de W. Mihatsch- ha coordinado un volumen colectivo (2017) y la sección temática "Fenómenos de intensidad semántico-pragmáticos: atenuación e intensificación" de la XX Deutscher Hispanistentag (2015), en la que intervinieron A. Briz, María Estellés, Adrian Cabedo y otros integrantes de Val.Es.Co., y es coautora (con M. J. Barros) de La cortesía en la comunicación (2013) La bibliografía no cesa de aumentar. Una parte considerable del vol. 13 (2016) de RILI se dedicó a "La atenuación y la intensificación desde una perspectiva semántico-pragmática". Y, como he dicho, hasta 17 Comunicaciones quedaron encuadradas en la sección que de ellas se ocuparon en este II Congreso.

${ }^{25}$ Pons Bordería $(2014,2016)$ cree que o sea puede ser marca de modalidad tanto de atenuación (Yo, o sea, no creo que esté bien eso) como de intensificación (jY va y me dice que no! O sea...). Y para Alf Monjour (2017), es fácil comprobar que poco tienen de polos opuestos, por ejemplo, en ciertos usos "dislocados" de nuestro imperfecto de indicativo: tú tenías un hermano ¿no?; ¿no le tocaba esta semana el turno de noche?; la fecha tope era mañana ¿no?...
} 
9. No es -o no debería ser-, sin embargo, la transcripción un freno en el quehacer investigador, pues siempre se puede -y se debe- utilizar la grabación o al vídeo. Sí lo son, y difíciles de salvar, los derivados de la escasa o nula textualidad del discurso (prototípicamente) coloquial, que obliga a contar con las condiciones -generales o específicas- del acto comunicativo (subjetividad, afectividad, espontaneidad, privacidad, informalidad, temática improvisada y no especializada, fuerte anclaje situacional y un largo etcétera), a las que se encuentran vinculados los específicos o peculiares fenómenos lingüísticos. Como he dicho, la carencia de herramientas idóneas para elaborar una macrosintaxis (sintaxis discursiva) que venga a resolver la insuficiencia o/e inadecuación de la microsintaxis (oracional) no ha impedido alcanzar logros en la exploración del proceso de producción de los enunciados. Poner de relieve, por ejemplo, que el "uso conversacional deja ver las etapas de su confección", o que el hablante puede "volver atrás sobre un sintagma ya enunciado", así como "insertar correcciones" y "retoques" e "introducir incisos" (Blanche-Benveniste 1998), puede parecer un avance menor, pero su fecunda explotación posterior (como la llevada a cabo por A. López Serena, desde su Tesis Doctoral -defendida en 2004 y publicada en 2007- hasta sus últimos trabajos, algunos aún en prensa) ha demostrado que ninguna aportación debería calificarse de menor en el estudio de la lengua coloquial.

10. Pero como de los problemas hasta aquí aludidos, y de otros, me vengo ocupando desde mis primeros escritos, intentaré decir algo de la repercusión que está teniendo el aumento de la atención a las variedades coloquiales en el modus operandi de los lingüistas que no o apenas se ocupan de ellas.

Para empezar, ha obligado a repensar el orden y aquilatar en qué medida han de combinarse las perspectivas semasiológica (la más transitada siempre) y onomasiológica (nunca marginada, pero, por lo general, utilizada como complementaria de la anterior y en la mayoría de las ocasiones sin precauciones teóricas).

Me referiré a una línea de indagación de la que se están beneficiando los historiadores de la lengua y de la literatura, calificada de fascinante por W. Oesterreicher. Me refiero a la búsqueda de huellas y vestigios de la oralidad -especialmente la coloquial- en los textos escritos disponibles del pasado, una labor que, claro es, ha de llevarse a cabo en "fuentes escritas idóneas para el rastreo de las variedades de la inmediatez". De lo contrario, los resultados pueden ser poco o nada convincentes. El análisis de tres decenas de conectores consecutivos en documentos coloniales de la Audiencia de Quito fechados entre 1563 y 1822 -de frecuencia muy desigual, pues la tercera parte de todas las ocurrencias corresponden a y (así), a gran distancia del segundo, con-que (13\%), y ninguno de los veintiocho restantes alcanza el $2 \%$ - lleva a E. Díez del Corral (2015) a la repartición de sus fuentes en dos grandes grupos, (más o menos) distantes o próximos. Tal distribución, no sólo le lleva a dar una explicación de, por ejemplo, la preferencia por conque en "contextos y situaciones comunicativas más inmediatas" y de "su abrupto descenso desde mediados del siglo XVIII", sino también a ir desmontando, de paso, conclusiones ajenas. Así, el hecho de que pues aparezca más en las cartas oficiales -pertenecientes, según la autora, "a un registro formal" y a la "lengua escrita"invalidaría lo que sostiene S. Iglesias (2000a); y el uso restringido de por (Io) tanto a los textos de "mayor rigidez expresiva" bastaría para "contradecir la hipótesis de Herrero (2006: 1733) acerca de su empleo coloquial". 
En esta clase de exploración, cada vez más cultivada ${ }^{26}$, toda cautela es poca, pues averiguar la vitalidad real de construcciones y variantes de formas discursivas que generalmente no pasan a la escritura, o lo hacen tarde y a muy pocos tipos de escritos, supone un reto tan problemático como seductor. La última de las secciones de la selección de trabajos reunidos en Sintaxis del español coloquial (Narbona 2015a) ${ }^{27}$, titulada "Oralidad y coloquialidad en la escritura", ocupa casi la mitad de las páginas, y habría que agregar otros posteriores (Narbona 2017, 2018). Como no quiero repetir lo ya expuesto, me limitaré a hacer una breve observación, simple llamada de atención, sobre una particular parcela de la escritura de lo oral que en la actualidad atrae tanto como preocupa.

11. Va camino de convertirse en una de las prácticas idiomáticas más extendidas la que se lleva a cabo chatendo o tuiteando (verbos que ya figuran en el Diccionario académico, al igual que los sustantivos chat, tuit y tuiteo y el adjetivo tuitero) o enviando (y recibiendo) mensajes por SMS (también incluido en el DRAE) o a través del wasap forma preferible a whatsapp según el reciente Libro de estilo académico (2018), que también admite guasap y guasapear, y que se decanta por yutubero, en lugar de youtuber- o facebook (que aún no ha recibido el visto bueno académico) ${ }^{28}$. Aunque nada puedo aportar en este terreno, quizás no sobre insistir en que tal oralidad escrita (o escritura de lo oral) poco tiene que ver con el ideal estilístico reiteradamente perseguido, desde Valdés ("escribo como hablo") hasta Juan Ramón Jiménez ("hay que escribir como se habla, no hablar como se escribe"). Y no debe perderse de vista que cada vez es más frecuente que lo que el receptor "lee" es la conversión automática en mensaje gráfico de lo "hablado" por un "emisor" no presente.

Nadie discute las grandes ventajas de las nuevas tecnologías, aunque sus consecuencias sean aún imprevisibles. Si bien tales formas de "hablar por escrito" jamás llegarán a suplantar al diálogo auténtico, especialmente al que no versa sobre lo práctico e inmediato, traslado la experiencia narrada por quien la estaba viviendo personalmente, una experta encargada de que la Comisión (de la que yo formaba parte como evaluador externo) designada por la Secretaria Xeral de Universidades de la Consellería de Cultura, Educación e Ordenación Universitaria (Xunta de Gaalicia) para evaluar los Grupos y Proyectos de Investigación aplicara correctamente los criterios establecidos. Al descubrir que su díscolo hijo preadolescente -con el que la comunicación directa se había hecho casi imposible- acogía las sugerencias que le hacía llegar por wasap, tomó la determinación de no usar otra vía, aunque ambos estuvieran sentados en la misma mesa ¿Caso extremo? Sin duda. Pero la escena haitual en que, en una reunión de jóvenes (o no tan jóvenes), cada uno permanece anclado a su móvil, aislado del entorno que lo rodea, ya ni choca. Con razón, las iniciativas encaminadas a prohibir o restringir

\footnotetext{
${ }^{26}$ Cfr. Díaz Bravo / Fernández Alcaide (2018). "Oralidad en la escritura” es el título del curso del Máster de Estudios Hispánicos Superiores que imparto desde hace años en la Universidad Hispalense. Próximamente aparecerá un número monográfico de Oralia con el mismo título, coordinado por A. López Serena y S. Iglesias.

${ }^{27}$ En la misma colección de la EUS en que ha aparecido un compendio de los de A. Briz (2018), que A. López Serena ha preparado como contribución a este merecido homenaje.

${ }^{28}$ Mientras redacto estas líneas, los medios informan del problema que ya supone para las empresas el que cada vez más trabajadores consulten varias veces por hora los mensajes recibidos (a bastantes de los cuales contestan), nada comparable al peligro de que algunos hacen algo parecido mientras conducen.
} 
su uso en los Centros escolares durante las horas lectivas son objeto de continuas y vivas discusiones.

Los numerosos estudios que se vienen ocupando de esta oralidad puesta por escrito algunos manifiestamente mejorables- no suelen llegar al fondo de lo que puede llegar a suponer, nada menos, un cambio cualitativo en los intercambios orales y escritos.

12. Tiene razón S. Gutiérrez Ordóñez (2015) al decir que aunque ahora sí pertenece a la zona de la proximidad comunicativa, se utiliza -al igual que eso sí- hasta en los registros orales más formales ${ }^{29}$. Acabo de comprobarlo en una emisión radiofónica. El locutor, tras haber anunciado por dos veces el final de un concierto -sin percatarse de que el pianista se disponía a ofrecer al público una propina tras otra-, cerró con estas palabras: "Concluye, ahora sí, el concierto que le hemos ofrecido desde...".

Pues bien, también yo, ahora sí, acabo, o, por lo menos, voy terminando. En 25 / 30 años, las puertas -e incluso algunas ventanas- de la investigación de la sintaxis del español coloquial se han abierto de par en par. No conviene, sin embargo, pasar de la legítima pasión ('afición vehemente') al apasionamiento ('afición excesiva'), y atribuirle más virtualidades de las que tiene, ya que puede resultar tan arriesgado como continuar obviándola o marginándola. Trabajar con anteojeras excluyentes puede conducirla a "morir de éxito", es verdad que por razones opuestas a las que terminaron casi estrangulando el avance de los paradigmas estructuralistas, tanto funcionales como sobre todo- formales. Si la idealizadora simplificación de la lengua permitía no contar con el significado léxico más que como mecanismo de comprobación, en ciertas indagaciones sobre el español coloquial, que se limitan a hacer ver efectos de sentido vinculados a muy variados e imprecisos factores contextuales que cualquiera puede constatar, se acaba por enterrar cualquier intento de formalización. Así no se hallarán las claves del soporte arquitectónico del contenido de las secuencias, que, es cierto, no están, ni mucho menos, sólo en lo verbalizado.

Como se ve, no resulta fácil orillar los problemas. Pulso la tecla "buscar", y compruebo que en lo hasta aquí escrito aparece ese término reiteradamente (y no pocas veces en citas ajenas, al igual que provisional), junto a otros empleados por variatio estilística: obstáculos, dificultades, escollos... Ana $\mathrm{M}^{\mathrm{a}}$ Vigara, en "Estudio del español coloquial: razones para el optimismo", presentación del citado número monográfico de EA correspondiente a 2002, dice "no compartir (en absoluto) la visión extremadamente pesimista mantenida desde hace muchos años -desde siempre, en realidad- por el profesor A. Narbona". Y lo argumenta con un extenso y alambicado razonamiento, construido a partir de una observación que hice en un trabajo de 2003. Sigo pensando que toda actitud crítica debe ser calificada de optimista, no en la primera acepción de optimismo que figura en el Diccionario académico ('propensión a ver y juzgar las cosas en su aspecto más favorable'), sino en la segunda ('pretensión de mejorarlas y, en la medida de lo posible, perfeccionarlas'), bastante menos ingenua, y que -ignoro por quéha desaparecido en la última edición, la del Centenario (2014).

\footnotetext{
${ }^{29}$ De los valores discursivos de ahora (que) se ocupa aquí mismo M. Borreguero.
} 
Lo que hace que me sienta decididamente optimista es el entusiasmo de los muchos que hoy se ocupan del español coloquial, bastantes de los cuales han participado en esta reunión para conmemorar los 25 años de Val.Es.Co., cuyos integrantes han convertido en un más que merecido homenaje a Antonio Briz. Como no me es posible referirme a la labor de todos ellos, sirva de botón de muestra la de Araceli López Serena, que en uno de sus escritos últimos (2017), que califica de "modesto primer paso", pone de manifiesto de modo clarividente que trascender el análisis atomizado de las actuaciones coloquiales resultará decisivo para la recuperación de una visión propiamente discursiva en las teorizaciones lingüísticas.

Lograr una descripción cada vez menos subjetiva e impresionista y más rigurosa y científica va a seguir siendo una empresa ardua, sin que baste la progresiva afinación de los instrumentos analíticos. Pero ¿no ha sido así siempre?

13. Y ya para terminar, ahora sí, de manera telegráfica, unas palabras sobre un par de líneas de actuación, muy distintas entre sí, entre las muchas pendientes.

En primer lugar, como en cualquier otra parcela de la lingüística hispánica, es preciso y urgente- recuperar la mejor tradición gramatical y fortalecer los puentes entre lo que se lleva a cabo a una y otra orilla del Atlántico. A los de este lado nos falta por saber mucho acerca de los usos del inmenso dominio hispanoamericano, cuyo conocimiento tanto debe a estudiosos de la talla de Bello, Cuervo, Keniston, Kany, y tantos otros. Y viceversa.

Se confiaba en que la aparición de la Nueva Gramática de la Lengua Española (RAE/ASALE 2009), lanzada como la gramática "del español de todo el mundo" iba, si no a acabar con la marginación de la lengua coloquial, sí a atenuarla, pero -se reconoce- los datos "de procedencia oral" han sido atendidos en ella "en proporción menor". En muy escasa medida, debería haber dicho. La comprensión de la técnica constructiva dominante en el español coloquial progresará en la medida en que se acierte a situar el foco en el proceso de producción de la interlocución y se supere el tratamiento de los enunciados monolocutivos como productos resultantes. No digo que sea inservible cuanto se averigüe con la mirada puesta en alguna(s) de las partes integradoras del discurso o en expresiones a las que se atribuye un especial papel marcador u ordenador. Pero sí que en bastantes estudios actuales la óptica interoracional continúa sin superar el ámbito de la microsintaxis. Y que la única posibilidad de conseguirlo es, ya lo he dicho, aplicar a las actuaciones idiomáticas propias de la inmediatez comunicativa la lupa de la perspectiva pragmática.

Claro que la tarea se complica cuando se proyecta sobre los testimonios del pasado que nos brindan determinados textos, literarios o no. La recuperación de los procedimientos de contextualización decisivos para inferir el sentido cabal, en particular los prosódicos, tropieza con obstáculos adicionales, si bien no insalvables. Como en la Sintaxis Histórica de la Lengua Española (SHLE), que coordina C. Company (2006, 2009, 2014), se ha reservado para la Cuarta (y última) Parte, aún en fase de preparación, la organización del discurso, es de esperar que la adopción de una óptica macrosintáctica 
lleve a prestar, por fin, mayor atención a la oralidad. Así que, también desde esta perspectiva diacrónica, lo mejor está por venir ${ }^{30}$.

En segundo término, no se puede perder de vista la repercusión social de la labor investigadora, que depende en gran medida de cómo se proyecte en el ámbito de la docencia. Es verdad que la enseñanza de la gramática, por sí sola, no va a mejorar la competencia oral (tampoco la escrita), pero la reflexión sobre los moldes y esquemas sintácticos de los que nos servimos todos casi todo el tiempo puede dinamizar la instrucción idiomática y contribuir no poco al desarrollo y enriquecimiento de la competencia lingüística. Del papel que cumple en la enseñanza a alumnos que tienen el español como primera lengua me he ocupado en más de una ocasión (Narbona 1993a, 1993b, 1997). En cuanto al que puede desempeñar en la destinada a no hispanohablantes, no dudo de que un riguroso conocimiento de la variedad que en primera instancia estos desean aprender facilitará la elaboración de materiales más adecuados. He dicho en primera instancia, porque no todos los que se proponen llegar a hablar (y escribir) nuestro idioma se conforman con ese escalón, sino que aspiran a dominar igualmente las variedades que les permiten intervenir en más situaciones comunicativas, para lo cual ha de contarse con la inmersión lingüística, con los poderosos medios de comunicación y, sobre todo, con la lectura (de verdaderos textos, se entiende).

Quiero añadir algo que no concierne específicamente a los estudios sobre el español hablado, y que -como todo lo que antecede- nada tiene de original. En una entrevista reciente, Massimo Livi Bacci, máxima autoridad mundial en demografía, decía que "tendría que ser una obligación de los profesores e investigadores invertir una parte de su tiempo en la divulgación". Si así piensa quien lucha denodadamente para que se tomen las medidas necesarias que permitan que este Planeta siga siendo habitable, con igual razón estamos obligados a difundir lo poco o mucho que vamos sabiendo quienes tratamos de averiguar de qué modo nos instala el idioma español a los aproximadamente 600 millones de hispanohablantes en la no pequeña parte del mismo en que vivimos, así como a los muchos que no la tienen como primera lengua pero aspiran a hacerla también suya.

\section{REFERENCIAS BIBLIOGRÁFICAS}

(Real) Academia Española y Asociación de Academias de la Lengua Española (2009): Nueva gramática de la lengua española, 2 vols., Madrid, Espasa.

(Real) Academia Española y Asociación de Academias de la Lengua Española (2018): Libro de estilo de la lengua española según la norma panhispánica, Barcelona, PlanetaEspasa.

ALBELDA, Marta (2007): La intensificación como categoría pragmática: revisión y propuesta, Frankfurt am Maim, Peter Lang.

\footnotetext{
${ }^{30}$ Durante el X Congreso Internacional de Historia de la Lengua Española, celebrado en Zaragoza (septiembre de 2015), E. Rojas y Juan P. Sánchez informaron del Proyecto de una Morfosintaxis histórica hispanoamericana, de anticipo del cual iba a servir el Primer Congreso que casi a continuación se celebraría en la Universidad suiza de Neuchâtel. El Segundo tuvo lugar a mediados de noviembre de 2018 en Sevilla. Como se ve, hay razones para pensar que la superación del desconocimiento recíproco al que acabo de aludir, ayudará a establecer las coincidencias y disparidades entre el español europeo y el de América.
} 
ALBELDA, Marta / BARROS GARCíA, M. J. (2013): La cortesía en la comunicación, Madrid, Arco/Libros.

ALBELDA, Marta / MIHATSCH, Wiltrud [eds.] (2017): Atenuación e intensificación en géneros discursivos, Madrid - Frankfurt, Iberoamericana - Vervuert.

ALONSO, A. (1925): "Español como que y cómo que", RFE, 12, 133-156.

ALONSO, A. (1935): "Noción, emoción, acción y fantasía en los diminutivos", Volkstum und Kultur der Romanen, 8 [Reproducido en Estudios lingüísticos. Temas españoles, 1951, 2a ed. 1961, Madrid, Gredos, 161-189].

ALVAR EZQUERRA, Manuel / VILLENA PONSODA, J. A. (1994): Estudios para un corpus del español, Universidad de Málaga.

AVILA / LASARTE / VILLENA, J. A. [eds.] (2008): El español hablado en Málaga II. Corpus oral para su estudio sociolingüístico. Nivel de estudios medios, Málaga, Sarriá.

AZORÍN, Dolores [coord.] (2002): Alicante corpus de español (Alcore), Universidad de Alicante.

BEINHAUER, W. (1929 [1978³]): El español coloquial, Madrid, Gredos.

BLANCHE-BENVENISTE, Claire (1997): Approches de la langue parlée en français, Paris, Ophrys.

BLANCHE-BENVENISTE, Claire (1998): Estudios lingüísticos sobre la relación entre oralidad y escritura, Barcelona, Gedisa.

BORREGUERO, Margarita (2015): "El gato, que ha tirado un vaso: ¿construcciones escindidas en el español coloquial?", RILI 13, 101-122.

BORREGUERO, Margarita I GÓMEZJORDANA, S. [eds.] (2015): Marqueurs du discours dans les langues romanes: une approche contrastive, Limoges, Lambert Lucas.

BOSQUE, Ignacio (1980): Sobre la negación, Madrid, Cátedra.

BOSQUE, Ignacio / DEMONTE, Violeta [dir.] (1999): Gramática descriptiva de la lengua española, 3 vols, Madrid, Espasa.

BRIZ, A. (Coord.) / Grupo Val.Es.Co. (1995a): La conversación coloquial (Materiales para su estudio), Universitat de València.

BRIZ, Antonio (1995b): "La atenuación en la conversación coloquial. Una categoría pragmática", en Cortés, L. [ed.], El español coloquial. Actas del I Simposio sobre análisis del discurso oral, Universidad de Almería, 101122.

BRIZ, A. (1996a): El español coloquial. Situación y uso, Madrid, Arco/Libros.

BRIZ, A. / GÓMEZ MOLINA, J. R. / MARTÍNEZ ALCALDE, Ma J / Grupo Val.Es.Co [eds.] (1996b): Pragmática y gramática del español hablado. Actas del II Simposio sobre análisis del discurso oral, Zaragoza, Univ. de ValènciaLibros Pórtico.

BRIZ, A. / CUENCA, Ma J. / SERRA, E. [eds.] (1997): Sobre l'oral i l'escrit. Quaderns de Filologia. Estudis Lingüistics, II. Facultat de Filologia, Univ. de València.

BRIZ, A. (1998): El español coloquial en la conversación. Esbozo de pragmagramática, Barcelona, Ariel.

BRIZ, A. / Grupo Val.Es.Co (2000): ¿Cómo se comenta un texto coloquial?, Barcelona, Ariel.

BRIZ, Antonio / PONS, Salvador / PORTOLÉS, José (coord.) (2008): Diccionario de partículas discursivas del español, < http://www.dpde.es>

BRIZ, A. / Grupo Val.Es.Co (2002): Corpus de conversaciones coloquiales (Anejo de Oralia), Madrid, Arco/Libros.

BRIZ, Antonio / Grupo Val.Es.Co. (2003): "Un sistema de unidades para el estudio del español coloquial", Oralia, 6, 7-61.

BRIZ, A. (2011): "La subordinación sintáctica desde una teoría de las unidades del discurso: el caso de las llamadas causales de la enunciación", en J. J. de Bustos / R. Cano I E. Méndez I A. López Serena (coordinadores), Sintaxis y análisis del discurso hablado en español. Homenaje a Antonio Narbona, Secretariado de Publicaciones de la Universidad de Sevilla, I, 137-154.

BRIZ, A / Grupo VAL.ES.CO. (2014): "Las unidades del discurso oral: la propuesta Val.Es.Co. de segmentación de la conversación (coloquial)", Estudios de Lingüística del Español, 35.1, 11-71.

BRIZ, Antonio (2018): Al hilo del español hablado. Reflexiones sobre pragmática y español coloquial, Editorial Universidad de Sevilla (EUS).

BRIZ, Antonio (en prensa): "La estrategia intensificadora en la conversación coloquial", en Los estudios sobre el español coloquial: viejos y nuevos enfoques [Universidad de Sevilla, 17-18 de noviembre de 2016].

CABEDO, Adrián (2007): "Marcas prosódicas del registro coloquial en la conversación", Cauce, 30, 41-56.

COMPANY, Concepción [dir.] (2006): Sintaxis histórica de la lengua española. Primera parte: La frase verbal [I y II], México: UNAMFondo de Cultura Económica.

COMPANY, Concepción [dir.] (2009): Sintaxis histórica de la lengua española. Segunda parte: La frase nominal [I y II], México: UNAMFondo de Cultura Económica.

COMPANY, Concepción [dir.] (2014): Sintaxis histórica de la lengua española. Tercera parte: preposiciones, adverbios y 
conjunciones. Relaciones interoracionales [I, II y III], México: UNAM-Fondo de Cultura Económica.

CORTÉS RODRÍGUEZ, Luis (1992): Estudios de español hablado. Aspectos teóricos y sintáctico-cuantitativos, Almería, Instituto de Estudios Almerienses.

CORTÉS RODRÍGUEZ, Luis (1994): Tendencias actuales en el estudio del español hablado, Universidad de Almería.

CORTÉS RODRÍGUEZ, Luis [ed.] (1995): El español coloquial. Actas del I Simposio sobre el español coloquial, Universidad de Almería.

CORTÉS RODRÍGUEZ, Luis (1996a): Español hablado. Bibliografía sobre aspectos teóricos y empíricos (morfosintácticos y sintácticopragmáticos). Anejos del AEF, $n^{\circ} 20$, Cáceres, Universidad de Extremadura.

CORTÉS RODRÍGUEZ, Luis (1996b): "Bibliografía: marcadores del discurso (I y II)", Español Actual, 63 y 64, 63-82, y 75-94.

CORTÉS RODRÍGUEZ, Luis (2002a): Los estudios del español hablado entre 1950 y 1999. Períodos, disciplinas y corrientes, Madrid, Arco/Libros.

CORTÉS RODRÍGUEZ, Luis (2002b): "Las unidades del discurso oral", Boletín de Lingüística (Caracas), 17, 7-29.

CORTÉS RODRÍGUEZ, Luis (2002c): "Español coloquial: concepto y status quaestionis", EA, 77-78, 27-41.

CORTÉS RODRÍGUEZ, Luis et alii [Coords.] (2007): Discurso y oralidad. Homenaje al profesor J. Jesús de Bustos Tovar (Anejos 3/1 y 3/2 de Oralia), Madrid, Arco/Libros.

CORTÉS RODRÍGUEZ, Luis / CAMACHO, Ma M. (2005): Unidades de segmentación y marcadores del discurso, Madrid, Arco/Libros.

CRIADO DE VAL, Manuel (1958, $3^{\text {a }}$ ed.): Gramática española y comentario de textos, Madrid, S.A.E.T.A.

DANILOVA, Oxana (2014): "Pa'que veas que te pido perdón en delante toda España". Pragmalingüística y análisis del discurso en los diálogos del talk show televisivo "Diario de Patricia" [2001-2011]. Aproximaciones teóricas y análisis, Lausanne, Sociedad Suiza de Estudios Hispánicos.

DÍAZ BRAVO, Rocío / FERNÁNDEZ ALCAIDE, Marta (2018): "La oralidad en el siglo XVI: lo literario y lo privado (I). Marcadores discursivos", BHS, 95.4, 357-381.

DÍEZ DEL CORRAL, Elena (2015): Los conectores consecutivos en documentos coloniales de la Audiencia de Quito (15631822), Madrid-Fráncfort: IberoamericanaVervuert. [Reseña de Antonio Narbona en
Revista Internacional de Lingüística Iberoamericana, 26 (2015), 210-217].

DÍEZ DEL CORRAL, Elena (2018): "De allí (es) que: ¿un conector consecutivo americano?", en $M^{a}$ L. Arnal et alii [eds.], Actas del X' CIHLE.

FERRER, Hang / PONS, Salvador [eds.] (2001): Las pragmática de los conectores y las partículas modales, Universitat de València.

FUENTES, Catalina (1998): "Vamos: un conector de gran complejidad", en Martín Zorraquino, $\mathrm{M}^{\mathrm{a}}$ A. / Montolío, E. (eds.), Los marcadores discursivos. Teoría y análisis, Madrid, Arco/Libros, 177-192.

FUENTES, Catalina (2000): "Lo oral en lo escrito: los enunciados parentéticos", Moenia, 5, 225246.

FUENTES, Catalina (2001): "La ambigüedad del término secuencia en el Análisis del discurso", en $M^{a}$ D. Muñoz et alii (eds.) Actas IV Congreso de Lingüística General, III, 11291141.

FUENTES, Catalina (2009): Diccionario de conectores y operadores del español, Madrid, Arco/Libros.

FUENTES, Catalina (2014): "Los límites del enunciado", Estudios de lingüística del español, 35,1, 137-160.

GAVIÑO, V. (2008): Español coloquial. Pragmática de lo cotidiano, Servicio de Publicaciones de la Universidad de Cádiz.

GILI GAYA, Samuel (1961[15ª ed., reimpresión, 1998]): Curso superior de sintaxis española, Barcelona, Vox, Biblograf, S. A.

GIRÓN, José Luis (2004): «Gramaticalización de los marcadores del discurso e historia de conque», Lexis, XXVIII (Homenaje a José Luis Rivarola), II, 157-198.

GIRÓN, José Luis (2011): «llativas, interordinación y consecutivas de enunciación», en J. Jesús de Bustos, R. Cano, E. Méndez y A. López Serena, eds., Sintaxis y análisis del discurso hablado en español. Homenaje a Antonio Narbona, Sevilla, Universidad de Sevilla, I, 551-566.

GUTIÉRREZ ORDÓÑEZ, Salvador (2015): Topicalización y génesis de estructuras", en E. Hernández Sánchez y M. Isabel López Martínez, eds., Sodalicia Dona. Homenaje a Ricardo Escavy Zamora, Universidad de Murcia, págs. 289-300.

HERRERO RUIZ DE LOIZAGA, Francisco Javier (2006): «La locución conjuntiva ya que: cronología y usos», en José Jesús de Bustos y José Luis Girón, eds., I, 825-840.

HERRERO RUIZ DE LOIZAGA, Francisco Javier (2016): «La formación del conector consecutivo de ahí (que)», en Araceli López Serena, Antonio Narbona y Santiago del Rey 
[Dir.], El español a través del tiempo. Estudios ofrecidos a Rafael Cano Aguilar, EUS, I, 563588.

HIDALGO NAVARRO, Antonio (1997a): La entonación coloquial. Función demarcativa y unidades del habla. Universitat de València.

HIDALGO NAVARRO, Antonio (1997b): "La estructura del discurso oral. En torno a las funciones lingüísticas de los suprasegmentos en la conversación coloquial", en Briz, A. I Cuenca, Ma J. / Serra, E., eds., pp. 147-163.

HIDALGO NAVARRO, Antonio (2001): "Modalidad oracional y entonación. Notas sobre el funcionamiento pragmático de los rasgos suprasegmentales en la conversación", Moenia, 7, 271-292.

HIDALGO NAVARRO, Antonio (2003): "Microestructura discursiva y segmentación informativa en la conversación coloquial", ELUA, 17, 367-385.

HIDALGO NAVARRO, Antonio (2004): "Las unidades de la conversación: acto y subacto como segmentos menores del análisis", Actas V Congreso de Lingüística General, 3365-3380.

HIDALGO NAVARRO, Antonio (2005): "Los sistemas de transcripción de la lengua hablada", Oralia, 8, 13-36.

HIDALGO NAVARRO, Antonio (2006a): Aspectos de la entonación española. Arco/Libros, Madrid.

HIDALGO NAVARRO, Antonio (2006b): "Estructura e interpretación en la conversación coloquial: el papel del componente prosódico", Revista de Filología, 24, 129-151.

HIDALGO NAVARRO, Antonio (2011): "Segmentación y discurso oral: notas sobre el papel demarcativo de la prosodia en la conversación", en J. J. de Bustos / R. Cano / E. Méndez / A. López Serena (coordinadores): Sintaxis y análisis del discurso hablado en español. Homenaje a Antonio Narbona, Secretariado de Publicaciones de la Universidad de Sevilla, I, 237-258.

HIDALGO NAVARRO, Antonio (2013): "La fono(des)cortesía: marcas prosódicas (des)corteses en español hablado. Su estudio a través de corpus orales", RLA, 51, 2, 127149.

HIDALGO NAVARRO, Antonio (2016): "Prosodia y (des)cortesía en los marcadores metadiscursivos de control de contacto: aspectos sociopragmáticos en el uso de bueno, hombre, ¿eh? y ¿sabes?", en A. M. Bañón et alii [eds.] Oralidad y análisis del discurso. Homenaje a Luis Cortés Rodríguez, Editorial Universidad de Almería, 309-335.
HIDALGO NAVARRO, Antonio (en prensa): "La entonación coloquial veinte años después: ¿avances o retrocesos?", Los estudios sobre el español coloquial: viejos y nuevos enfoques, Universidad de Sevilla, 17-18 de noviembre de 2016.

IGLESIAS, Silvia (2000a): «La evolución histórica de pues como marcador discursivo hasta el siglo XV», Boletín de la Real Academia Española, LXXX, 209-307.

IGLESIAS, Silvia (2000b): «Oralidad y escritura en la Edad Media: observaciones sobre la historia de ca y que», Oralia, 3, 277-296.

IGLESIAS, Silvia (2015): "Sintaxis, texto y discurso: la historia de por cierto", en Borreguero, M. / Gómez-Jordana, S. (eds.): Marqueurs du discours dans les langues romanes: une approche contrastive. Limoges: Lambert Lucas, 277-315.

KERBRAT-ORECCHIONI, C. (1986): La enunciación. De la subjetividad en el lenguaje, Buenos Aires, Hachette.

$\mathrm{KOCH}$, P. / OESTERREICHER, W. (1990): Gesprochene Sprache in der Romania: Französisch, Italianisch, Spanisch, Tübingen, Niemeyer (=Romanistische Arbeitshefte, 31). Versión española de Araceli López Serena (2007): Lengua hablada en la Romania: español, francés, italiano, Madrid, Gredos.

$\mathrm{KOCH}$, P. I OESTERREICHER, W. (2000): "Langage parlé et langage écrit", en Holtus, G. / Metzeltin, M. I Schmitt, Chr. [Hrsg.] Lexikon der Romanistischen Linguistik, Band 1, Tübingen, Niemeyer.

LASARTE, M. C. / SÁNCHEZ, J. M. / ÁVILA, A. / VILLENA PONSODA, J. A. [Eds.] (2009): El español hablado en Málaga III: Corpus oral para su estudio sociolingüístico. Nivel de estudios superior, Málaga, Sarriá.

LÓPEZ GARCÍA-MOLINS, Ángel (1994): Gramática del español. I: La oración compuesta, Madrid, Arco/Libros.

LÓPEZ GARCÍA-MOLINS, Ángel (2016): "Metodología de estudio de la oralidad", en A. M. Bañón et alii [eds.] Oralidad y análisis del discurso. Homenaje a Luis Cortés Rodríguez, Editorial Universidad de Almería, 357-368.

LÓPEZ GARCÍA-MOLINS, Ángel (2018): Prolegómenos a un estudio de la variación lingüística, Valencia, Tirant Humanidades [Reseña de A. Narbona en Estudios de Lingüística del Español, 2018].

LÓPEZ SERENA, Araceli (2007): Oralidad $y$ escrituralidad en la recreación literaria del español coloquial, Madrid, Gredos.

LÓPEZ SERENA, Araceli / BORREGUERO, Margarita (2010): "Los marcadores del discurso y la variación lengua hablada vs. 
lengua escrita", en Ó. Loureda / E. Acín (coord.), 415-495.

LÓPEZ SERENA, Araceli [ed.] (2014): Historia de la lengua e intuición. Monográfico de RILCE. Revista de Filología Hispánica, 30/3, Pamplona, Universidad de Navarra.

LÓPEZ SERENA, Araceli (2017): "Hacer (cosas con) palabras: la discursividad como universal genérico-esencial del lenguaje", Círculo de lingüística aplicada a la comunicación (Clac), 69, 175-216.

LÓPEZ SERENA, Araceli (2018a): "Gramática, discurso, oralidad: las formas invisibles de la polaridad positiva en español coloquial", Anuari de Filologia. Estudis de Lingüística, 8, 57-83.

LÓPEZ SERENA, Araceli (2018b): "Hacia una revisión de la caracterización semántica y discursiva de la locución y eso que en español actual", ELUA, 32, 195-217.

LÓPEZ SERENA, Araceli / IGLESIAS, Silvia [eds.] (en prensa): Oralidad en la escritura, Núm. Monográfico de Oralia.

LOUREDA, Óscar / ACÍN, Esperanza [coords.] (2010): Los estudios sobre marcadores del discurso en español, hoy, Madrid, Arco / Libros.

MARTÍN ZORRAQUINO, M ${ }^{a}$. Antonia I MONTOLÍO, Estrella (1998): Los marcadores del discurso. Teoría y análisis, Madrid, Arco/Libros.

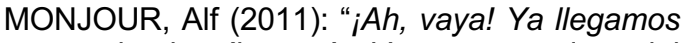
a donde íbamos! Vaya marcador del discurso", en Aschenberg, H. / Loureda, Ó. (eds.): Marcadores del discurso. De la descripción a la definición. Madrid · Frankfurt, Iberoamericana - Vervuert, 343-373.

MONJOUR, Alf (2017): “'¿Cómo que las 6:45? ¡Si a esa hora es cuando salía el tren!', ¿ ¿Se sabe algo de la reunión, era a las 11, no?'” Usos dislocados del imperfecto español como estrategias de atenuación e intensificación", en Albelda, M. / Mihatsch, W., eds., Atenuación e intensificación en géneros discursivos. Madrid . Frankfurt, Iberoamericana - Vervuert.

MOYA, Juan Antonio [Coord.] (2008): El español hablado en Granada. Corpus oral para su estudio sociolingüístico. II: Nivel de estudios medio, Granada, Universidad.

NARBONA, Antonio (1988): "Sintaxis coloquial: prolemas y métodos", LEA, X, 81-106. [Recogido en Narbona 2015a, 135-146]

NARBONA, Antonio (1990): "¿Es sistematizable la sintaxis coloquial?", en Actas del Congreso de la Sociedad Española de Lingüística. XX Aniversario, II, Madrid, Gredos, 1030-1043. [Recogido en Narbona 2015a, 45-62]
NARBONA, Antonio (1991): "Sintaxis coloquial y análisis del discurso", RSEL, 21/2, 187-204. [Recogido en Narbona 2015a, 181-194]

NARBONA, Antonio (1992): "La andadura sintáctica coloquial en El Jarama", en M. Ariza [ed.] Problemas y métodos en el análisis de textos. In memoriam A. Aranda, Sevilla, Universidad, 227-260. [Recogido en Narbona 2015a, 299-329]

NARBONA, Antonio (1993a): "Notas sobre sintaxis coloquial y realismo en la literatura narrativa española", en J. A. Bartol Hernández et alii [eds], Estudios Filológicos en Homenaje a Eugenio de Bustos Tovar, I, Salamanca, Universidad, 163-169. [Recogido en Narbona 2015a, 251-256]

NARBONA, Antonio (1993b): "La enseñanza de la gramática en la Educación Secundaria Obligatoria", en Actas del I y II Simposios de Actualización Científica y Pedagógica, Madrid, Asociación de Profesores de Español, 45-54.

NARBONA, Antonio (1993c): "Los estudios gramaticales y la enseñanza del español en la Educación Secundaria", en Actas del IV Simposio de actualización científica y didáctica de Lengua Española y Literatura, Sevilla, Asociación Andaluza de Profesores de Español "Elio A. de Nebrija", 60-70.

NARBONA, Antonio (1994): "Hacia una sintaxis del español coloquial", en CLE, 721-740. [Recogido en Narbona 2015a, 45-62]

NARBONA, Antonio (1995): "Español coloquial y variación lingüística", en Luis Cortés [ed.] (1995), 31-42.

NARBONA, Antonio (1996a): "Sintaxis del español coloquial: algunas cuestiones previas", en Briz, E. A. / Gómez Molina, J. R. / Mártinez Alcalde, $\mathrm{M}^{\mathrm{a}} \mathrm{J} / \mathrm{Grupo}$ Val.Es.Co [eds.] (1996), 157-175. [Recogido en Narbona 2015a, 159-180]

NARBONA, Antonio (1996b): "Como que y cómo que, setenta años después", Lexis, $\mathrm{XX}$, Centenario de A. Alonso: 1896-1996, 509523.

NARBONA, Antonio (1996c): "Sintaxis y Pragmática en el análisis del discurso coloquial", en T. Kotschi, W. Osterreicher y K. Zimmermann (eds.), El español hablado y la cultura oral en España e Hispanoamérica, Frankfurt am Main . Madrid, Vervuert . Iberoamericana, 223-243. [Recogido en Narbona 2015a, 195-209]

NARBONA, Antonio (1997): "Los modelos de explicación lingüística y la nueva Enseñanza Secundaria Obligatoria", en García Wiedemann, E. / Montoya, Ma I. / Moya, J. A. (eds.), Enseñar y Aprender Lengua Española, Granada, 47-72. 
NARBONA, Antonio (2000a): "Sintaxis coloquial", en M. Alvar [Coord.] Gramática española, Barcelona, Ariel, 463-478. [Recogido en Narbona 2015a, 117-134]

NARBONA, Antonio (2000b): "Sintaxis histórica y sintaxis descriptiva: interrelación y limitaciones", Homenaje a V. Lamíquiz, Madrid, U.N.E.D., 665-681.

NARBONA, Antonio (2001): "Diálogo literario y escritura(lidad)-oralidad", en R. Eberenz [ed.] Diálogo y oralidad en la narrativa hispánica moderna. Perspectivas literarias y lingüísticas, Madrid, Verbum, 189-208. [Recogido en Narbona 2015a, 331-344]

NARBONA, A. (2002a): "Sobre evolución sintáctica y escritura-oralidad", Actas del V Congreso Internacional de Historia de la Lengua Española, I, Madrid, Gredos-CAM, 133-158. [Recogido en Narbona 2015a, 233249]

NARBONA, A. (2002b): "Sintaxis y Oralidad", en A. Bernabé y otros (eds.): Actas del II Congreso de la Sociedad Española de Lingüística. Presente y futuro de la lingüística en España. La Sociedad de Lingüística 30 años después, I, Madrid, Infoprint, 189-198.

NARBONA, A. (2003a): "Oralidad: los datos y las gramáticas", en J. J. de Bustos [ed.] Actas del Seminario Textualización y oralidad, Madrid, Instituto Universitario "Menéndez Pidal", 1325. [Recogido en Narbona 2015a, 105-116]

NARBONA, A. (2003b): "Variación y sintaxis", en Lengua, variación y contexto. Estudios dedicados a H. López Morales, Madrid, Arco/Libros, 763-774.

NARBONA, A. (2004): "Cambios y tendencias gramaticales en el español moderno", en R. Cano (Coord.), Historia de la lengua española, Barcelona, Ariel, 1011-1035.

NARBONA, A. (2007a): "Cuando lo coloquial se convierte en literario", en I. Delgado / A. Puigvert (eds.) Ex admiratione et amicitia. Homenaje a R. Santiago, II, Madrid, Ediciones del Orto, 849-858. [Recogido en Narbona 2015a, 345-355]

NARBONA, Antonio (2007b): «Sintaxis de la escritura de lo oral en los diálogos del Quijote», en Luis Cortés, Antonio M. Bañón, María del Mar Espejo y José Luis Muñío [eds.], Discurso y oralidad. Homenaje al Profesor José Jesús de Bustos Tovar, Madrid, Arco/Libros, 65-111 [Recogido en Narbona 2015: 257-297] [Recogido en Narbona 2015a, 257-297]

NARBONA, Antonio (2008a): "La problemática descripción del español coloquial", en E. Stark / R. Schmidt-Riese / E. Stoll (Hrsg.), Romanische Syntax im Wandel, Tübingen,
Gunter Narr Verlag, 549-565. [Recogido en Narbona 2015a, 91-102]

NARBONA, Antonio (2008b): "Qué comparar en sintaxis histórica de la lengua española", en Company, C. / Moreno de Alba, J. [eds.] Actas VII CIHLE, II, Madrid, Arco/Libros, 2255-2271.

NARBONA, Antonio (2009): "La felicidad es algo que pueda compartirse. Nota (sin notas) sobre un empleo del subjuntivo", en M. Veyrat / E. Serra (eds.), La lingüística como reto epistemológico y como acción social. Estudios dedicados al profesor Ángel López García con ocasión de su sexagésimo aniversario, Madrid, Arco/Libros, I, 489-500. [Recogido en Narbona 2015a, 357-369]

NARBONA, Antonio (2012a): "Fuentes escritas para el estudio de la oralidad", en E. Montero I C. Manzano (eds.), Actas VIII Congreso Internacional de Historia de la Lengua Española, I, Santiago de Compostela, 343356.

NARBONA, Antonio (2012b): "Más allá de la sintaxis", en T. Jiménez Juliá et alii (eds.), Cum corde et in nova grammatica. Estudios ofrecidos a G. Rojo, Universidad de Santiago de Compostela, 617-624.

NARBONA, Antonio (2012c): "Diálogos bajo control", en V. Béguelin-Argimón / G. Cordone / M. de la Torre (eds.), En pos de la palabra viva: huellas de la oralidad en textos antiguos. Estudios en honor al profesor Rolf Eberenz, Peter Lang, 247-267. [Recogido en Narbona 2015a, 213-231]

NARBONA, Antonio (2012d): "Los estudios sobre el español coloquial y la lingüística", RSEL, 42/2, 5-31. [Recogido en Narbona 2015a, 7390]

NARBONA, Antonio (2013a): "Novedades teóricas en la NGRAE", Orillas, 2. Univ. di Padova.

NARBONA, A. (2013b): "Cuando es el otro el que subordina", en S. Saffi, S. Caddéo, S. Gencarau, R. Timoc-Bardy (coords.), Studia Universitatis Babes-Bolyai. Philologia, 58 (Linguistique comparée des langues romanes LICOLAR, La subordination à travers les langues romanes. Hommage au Professeur Henri-José Deulofeu, 175-186. [Recogido en Narbona 2015a, 147-156]

NARBONA, Antonio (2015a): Sintaxis del español coloquial, Sevilla: Editorial Universidad de Sevilla (EUS).

NARBONA, Antonio (2015b): "Cuestión de límites ¿o de limitaciones?, en C. Galán et alii (coords.), El discurso de la gramática. Estudios ofrecidos a José Manuel González Calvo, Cáceres, Servicio de Publicaciones de la Universidad de Extremadura, 267-275. 
NARBONA, Antonio (2016a): "Las variedades sintácticas en la NGRAE', en A. M. Bañón et alii [eds.], Oralidad y análisis del discurso. Homenaje a Luis Cortés Rodríguez, Editorial Universidad de Almería, 489-504.

NARBONA, Antonio (2016b): "El arte de hablar y escribir correctamente", BRASBL, 44, 133146.

NARBONA, Antonio (2017): "El diálogo de igual a igual entre Don Quijote y Sancho", en A. Asensi, ed., Miguel de Cervantes (1616-2016), Málaga, Instituto de Academias de Andalucía / Consejería de Economía y Conocimiento de la Junta de Andalucía, 29-48.

NARBONA, Antonio (2018): "Oralidad en la escritura y sintaxis histórica del español", en $\mathrm{M}^{\mathrm{a}} \mathrm{L}$. Arnal et alii [eds.], Actas del XCIHLE, II, 1387-1408.

NARBONA, Antonio (en prensa): "iAnda que ha tardado (bastante) en dejarla! ¡Anda que no se lo he dicho (yo) (muchas) veces!", en Homenaje a J. L. Girón, Madrid, UCM.

OCTAVIO DE TOLEDO Y HUERTA, Álvaro S. (2001-2002): “¿Un viaje de ida y vuelta?: la gramaticalización de vaya como marcador y cuantificador", Anuari de Filologia, XXIII-XXIV, 47-71.

OESTERREICHER, Wulf (2004): «Textos entre inmediatez y distancia comunicativas. El problema de lo hablado escrito en el siglo de Oro», en Rafael Cano (coord.), Historia de la lengua española, Barcelona, Ariel, 729-769.

PADILLA, Xose A. (2005): Pragmática del orden de palabras, Universidad de Alicante, 2005.

PADILLA, Xose A. (2006): "Las unidades monológicas (intervención, acto y subacto) y el orden de palabras: una guía para su análisis en el discurso hablado", en $\mathrm{M}$. Casado, R. González Ruiz y $\mathrm{M}^{\mathrm{a}} \mathrm{V}$. Romero Gualda, coord., Análisis del discurso: lengua, cultura, valores, I, 677-690.

PAYRATÓ, Lluís (2018): Introducción a la pragmática. Una perspectiva sobre el lenguaje en acción, Madrid, Síntesis.

PEDROVIEJO, Juan Manuel (2017): La gramática argumental aplicada a El Arcano de la Quina de José Celestino Mutis, Lincolm $\mathrm{GmbH}$, Linguistics Edition, 110

PÉREZ BÉJAR, Víctor (2018a): Pragmagramática de las estructuras suspendida. Tesis Doctoral, Universidad de Sevilla.

PÉREZ BÉJAR, Víctor (2018): (2018b): “Te ayudo. Como no tengo otra cosa que hacer...Las construcciones causales suspendidas con como en una gramática del discurso", E. Brenes / M. González-Sanz / F. J. Grande [coords.], Enunciado y discurso: estructuras y relaciones, Sevilla, EUS, 63-80.
PÉREZ GIL, Otilia (2017): Las causales en la oralidad. Los enunciados con porque, Salamanca, Universidad.

POLANCO, Fernando (2013): "Redes polisémicas y niveles de interpretación: Representación semántica de unidades lingüísticas complejas: el caso de vamos", ELUA, 27, 199-250.

POLANCO, Fernando (2014a): "Modalidad, ilocución y refuerzo argumentativo: el caso de vamos y vaya en el español coloquial", Oralia, 17, 347-373.

POLANCO, Fernando (2014b): "Variación funcional y polisemia en la descripción de marcadores conversacionales en español peninsular. El caso de vaya", RSEL, 44/2, 131-164.

POLANCO, Fernando (2017): "La locución discursiva pero vamos/vaya como reorganizador discursivo", Signos, 50/93,7195.

PONS BORDERÍA, Salvador (1998): Conexión y conectores. Estudio de su relación en el registro informal de la lengua, València, Universitat de València.

PONS BORDERÍA, Salvador (2014): «El siglo XX como diacronía: intuición y comprobación en el caso de o sea», en López Serena, A. (ed.): Historia de la lengua e intuición. Monográfico de RILCE. Revista de Filología Hispánica, 30/3, Pamplona, Universidad de Navarra, 985-1016.

PONS BORDERÍA, Salvador (2016): "Evolución diacrónica de o sea", BRAE 96, 291-350.

PONS BORDERÍA, Salvador / LOUREDA, Óscar [eds.] (2018): Beyond Grammaticalization and Discourse Marker. New Issues in the Study of Language Change. Leiden / Boston, Brill.

PONS RODRÍGUEZ, Lola (2010): "Los marcadores del discurso en la historia del español", en Loureda, Ó. / Acín, E. (coords.), Los estudios sobre marcadores del discurso en español, hoy., Madrid, Arco/Libros, 523615.

PORTOLÉS, José (2001): Marcadores del discurso, Barcelona, Ariel.

PUGA LARRAÍN, Juana (1997): La atenuación en el castellano de Chile: un enfoque pragmalingüístico, Universitat de València.

RAMOS, / SERRADILLA, Ana (2000): Diccionario Akal del español coloquial. 1492 expresiones y más...(con sus equivalencias en inglés), Madrid, Akal.

REY, Santiago del (2015): “¿Qué es lo que oigo? Historia de una fórmula conversacional en el diálogo literario castellano", en RILI, 13, 81100. 
REY, Santiago del (2018): "Lo marcado y lo no marcado en la cadena de variedades: apuntes para una nueva propuesta" en K. Grübl, T. Gruber, K. Jacob y Th. Scharinger (eds.): Was bleibt von kommunikativer Nähe und Distanz?, Tübingen, Narr, ScriptOralia.

RIDRUEJO, Emilio (2002): «Para un programa de pragmática histórica del español», en $\mathrm{M}^{\mathrm{a}}$ Teresa Echenique y Juan Pedro Sánchez Méndez, eds., Actas del $V$ Congreso Internacional de Historia de la Lengua Española, Madrid, Gredos, I, 159-177.

SANTOS RÍO, Luis (2003): Diccionario de partículas, Salamanca, Luso-Española de Ediciones.

SCHWENTER, Scott A. I PONS BORDERÍA, Salvador (2005): «Por poco (no). Explicación sincrónica y diacrónica de sus componentes de significado», Lingüística Española Actual, XXVII/1, 131-156.

SIMONE, Raffaele (1997): “¿Cuál es la lengua de default en un ambiente de variación?", en A. Narbona / M. Ropero (eds.), El habla andaluza. Actas del Congreso del habla andaluza, Sevilla, SPHA, 29-41.

SORNICOLA, Rosanna (1981): Sul parlato, Bologna, II Mulino.

SORNICOLA, Rosanna (2002): "La variazione dialettale nell'area costiera napoletana. II progetto di un Archivio di testi dialettali parlati”, Bolletino Linguistico Campano, 1, 131-155.

SOSA, J. M. (1999): La entonación del español. Su estructura fónica, variabilidad y dialectología, Madrid, Cátedra.

TANGHE, Sanne (2015): «Prosodia y polifuncionalidad de los marcadores anda, vamos, vaya y venga», Círculo de Lingüística Aplicada a la Comunicación, 62, 125-147.

TANGHE, Sanne (2016): Marcadores derivados de verbos de movimiento. Una aproximación cognitiva a su polifuncionalidad, BerlínBoston, De Gruyter.

TOURATIER, Christian / ZAREMBA, Charles [dir.] (2007): La negation. Travaux Cercle linguistique d'Aix-en-Provence.

VALLEJO, José (1922): «Notas sobre la expresión concesiva», Revista de Filología Española, 9, 40-51.

VIGARA, Ana $\mathrm{M}^{\mathrm{a}}$ (1992 [2 $2^{\mathrm{a}}$ ed. 2005]): Morfosintaxis del español coloquial. Esbozo estilístico, Madrid, Gredos.

VIGARA, Ana $M^{a}$ (2002): «Estudio del español coloquial: razones para el optimismo», EA, 77$78,5-25$

VILA PUJOL, M. Rosa / Grupo GRIESBA (2001): Corpus del español conversacional de Barcelona y su área metropolitana, Universitat de Barcelona.

VILA RUBIO, María Nieves (1990): Aspectos de sintaxis coloquial en documentos aragoneses del siglo XV, Zaragoza, Diputación General de Aragón.

WILLEMS, D. (1998): "Donées et théories en linguistique: Réflexions sur une relation tumultueuse et changeante», en M. Bilger, K. van den Eynde y F. Gadet (eds.), Analyse linguistique et approches de l'oral Recueil d'études offerts en hommage à Cl. BlancheBenveniste, Leuven-Paris, Preeters, 79-87.

ZUBIZARRETA, M ${ }^{a}$ L. (1999): "Las funciones informativas: tema y foco", en I. Bosque / V. Demonte [dir.], Gramática descriptiva de la lengua española, 3, 4215-4244. 